\title{
Financial Inclusion in India: An Empirical Study of Unorganized Sector in Gujarat
}

\author{
Manoj Kumar Sahoo, Mudra Gomkale \\ Pandit Deendayal Petroleum University, Gandhinagar, Gujarat, India \\ sahoomanoj1@rediffmail.com
}

\begin{abstract}
The Indian economy being one of the emerging economies among the twenty global traders with annual growth rate projected at 7.4\% for the year 2014-15 as compared to 6.9\% growth in the fiscal year 2013-14.With second largest population in world and third largest purchasing power parity India suffers from socio cultural issues such as poverty and unemployment. The major question here is on sustainable growth of the nation. An easy and affordable access to financial and banking services accounts for the financial inclusion particularly for the lower and vulnerable sections of the society. More the people earn more they invest and save more. In order to address the sate of inequality it is essential to give major priority for achieving 100 per cent or near to $100 \%$ Financial Inclusion. Gujarat being a rapidly growing state contributing $10 \%$ to India's GDP despite efficient growth it lags behind in Financial Inclusion .The paper on Financial Inclusion in India: An empirical study of unorganized sector aims to do an in depth research in order to reason out for the unaccounted un-organized sector of the state. Unorganized sector refers to the people who drive their economic activities on daily basis by unregistered business firms or self employment. Dealing with primary data on Different parameters of Financial Inclusion pertaining to unorganized sector of Gujarat state and a regression model namely Logit Model is estimated to examine the relationship of Financial Inclusion parameter on various determining variables. Research work is on-going; we expect that Gujarat government has to focus on more spread of awareness among people of Gujarat who are not able to avail economic growth benefits equally despite an excellent performance in HDI, per capita GNI and other economic development parameters.
\end{abstract}

Keywords: Financial Inclusion, Unorganized sector in India, Gross State Domestic Product, Sustainable development, Inclusive growth

\section{Introduction}

For the seventh largest nation in the world having second highest population, major challenge is to cater to the needs of the people. Like drinking water, clothing and food are basic necessities for survival; access to financial services and products too becomes basic amenities for development and growth of human potential. India has focused on poverty reduction as a long term development policy goal since the time of independence in 1947. But along with it, India has remained at the forefront of designing strategies to eradicate poverty and develop an environment based on inclusive growth and for that matter; the focus on Financial Inclusion was laid back in 1969. From 2000's it has been an area of prime focus for the Government of India and the Reserve Bank of India. Designing several programs and schemes in order to improve financial inclusion and to bring in more and more people under financial ambit has been the main objective under it. The shift in the focus from poverty alleviation to financial inclusion summarizes the mixed results India has had in the last five decades of development planning strategies. Over the decades that's why the focus from target specific development approaches to high growth achievement got shifted for 'trickle down effect' to take place on those segment of the population who are at the bottom of the pyramid. But the planned development exercises by the successive five year plans failed to include a sizable part of that population under the mainstream development fold. And for that reason, off late Indian government's policy has been centered on inclusive growth and financial inclusion. Indian policy makers have invariably meant inclusive growth by broad-based and shared benefits of economic development to all sections of people where people become part of the process of development, rather than simply the target of it. And for this to be achieved, financial inclusion becomes the complementary condition whereby a comprehensive and holistic process of easy access to financial services and credit to the marginalized and vulnerable sections of the population is ensured. So the process of including the excluded into the financial services mainstream assumes the possibility of expansion of economic opportunities available to the unserved and underserved segments of 
the society. In this respect however, expansion of the formal financial sector like banking, postal, microfinance etc. ensuring reach to this segment becomes crucial requirement of financial inclusion.

Overview of Financial Inclusion in India and Gujarat: Despite broad international consensus regarding the importance of access to finance as a crucial poverty alleviation tool, it is estimated that globally over two billion people are currently excluded from access to financial services. The situation is worse in most of the least developed countries (LDCs), where more than 90 per cent of the population is excluded from access to the formal financial system (United Nations, 2006). ${ }^{1}$ India has made several efforts to enlarge the reach of formal financial sector over the years, in particular, banking sector in India has grown both in terms of bank penetration, expansion of financial services and technological innovations i.e. use of ATMs and use of smart cards or plastic money such as credit cards, debit cards and others likewise. However, this expansion has not been able to cover all the part of workforce. As per NSSO data 45.9 million farmer households in the country (51.4\%), out of a total of 89.3 million households does not access credit, either from institutional or noninstitutional sources. Rangarajan Committee Report, (2008) despite the vast network of bank branches, only 27 per cent of total farm households are indebted to formal sources, of which one-third also take credit from informal sources (Ray \& Rout, 2014). So, this leads to the implication that most financially excluded especially are those which come under the informal sector. For those in the formal sector, access and usage of bank services is mandatory given to the norms and conditions of the companies registered under government. While those of the informal sector- i.e. marginal farmers, farm labor, daily wage earners, which account for $60 \%$ of the working population is less accounted.

Figure: India's Position in Financial Inclusion Compared to Other Countries (Per 0.1 Million Adults) (As per cent of GDP)

\begin{tabular}{llllll}
\hline Sr. No. & Country & No. of Branches & No. of ATMs & Bank Credit & Bank Deposit \\
\hline 1 & India & 10.91 & 5.44 & 43.62 & 50.11 \\
2 & Austria & 11.81 & 48.16 & 35.26 & 32.57 \\
3 & Brazil & 13.76 & 120.62 & 29.04 & 47.51 \\
4 & France & 43.11 & 110.07 & 56.03 & 39.15 \\
5 & Mexico & 15.22 & 47.28 & 16.19 & 20.91 \\
6 & UK & 25.51 & 64.58 & 467.97 & 427.49 \\
7 & USA & 35.74 & 173.75 & 46.04 & 53.14 \\
8 & Korea & 18.63 & 250.29 & 84.17 & 74.59 \\
9 & Philippines & 7.65 & 44.88 & 27.57 & 53.02 \\
\hline
\end{tabular}

Source: World Bank, Financial Access Survey (2010).

As India is developing and is rapidly evolving at global level it becomes crucial for the nation to meet the supreme most challenge of Financial Inclusion as it is linked to sustainable growth, and development of the nation. Moreover, massive problems of black money flow can be regulated and diminished over a period of time by enlarging the network of formal financial services to the unserved segment. Though bank services have evolved and expanded over the years not all are able to gain fruits from these facilities. There are several reasons for such low level of financial inclusion such as lack of financial literacy, low levels of income, preference to follow traditional way of saving and borrowing money when required among others. As a result Indian economy is deviating from achieving sustainable economic and social growth. RBI and Government of India in 2005 had taken series of efforts in order to achieve financial inclusion such as increase in number of SHG-bank linkages, spread of business correspondents (BCs)/business facilitators, easing KYC (Know Your Customer) norms, electronic transfer benefits, separate plans for rural and urban financial inclusion and so on. Financial Inclusion aims to provide easy access to finance at affordable costs to the poor and vulnerable sections of society. Financial Inclusion also encompasses the broadening of financial services to those who do not have access to formal sources of finance, the deepening of financial services to those who have minimal access, and greater financial literacy and consumer protection so that those who are offered products can make appropriate choices (Rajan, 2014). "The RBI's approach to financial inclusion has been structured,

\footnotetext{
${ }^{1}$ As quoted in Meher, 2014.
} 
planned, and integrated focusing on supply side constraints" (Shamaka \& Gakhar, 2015). So far as India's position in financial inclusion vis-à-vis the major developing and developed countries is concerned, the extent of financial inclusion in India is found to be comparatively lower. Figure shows that India had 10.91 bank branches and 5.44 ATMs per 0.1 million adults, which was lower than most developed countries and emerging economies like UK, US, France, Brazil, Mexico etc. No. of ATMs per 0.1 million population had improved to 8.90 in India by 2011. (IMF, financial Access Survey, 2011) However, availability of bank credit and deposit were 43.6 per cent and 50.1 per cent respectively, which were lower than developed countries like US, UK etc but better than emerging economies like Mexico and Brazil.

Although the number of banks have increased over the years, further after the Prime Minister's Jan Dhan Yojana basic savings accounts have raised too right from 7.5 Crore to 10 Crore bank accounts in January 2015. Banks are encouraged to promote banking services considering it as business opportunities rather than charity by leveraging technology to drive financial inclusion. The major question lies whether these bank accounts are used or accessed at regular basis. This scheme has made tremendous progress in terms of creating bank account holders and accessibility. Of all 29 states in India, Gujarat is located in the western part of India also known as Jewel of India. It is also known for its textile production and also the region has a strong hold on agricultural and industrial segment. Cash crop such as cotton, groundnut, castor, tobacco and other crops are grown extensively. Moreover, industries in jewellery segment especially the diamond and silver industries along with automobile and petrochemicals have well flourished. Gross State Domestic Product (GSDP) of Gujarat is marked at Rs.7, 65,638 crore for year 2013-14 and Rs. 867,643 crore for the year 2014-15. Accounting for 5\% of country's population the state contributes more than 7\% of Indian GDP and in particular, $13 \%$ of Manufacturing and $11 \%$ of Primary sector output of the country. Annual average GSDP growth rate of $9.1 \%$ during $2008-11$ was well above the national growth rate of $8.2 \%$ during the same period. Despite having outstanding growth in economy it ranks moderately low in Financial Inclusion. As per CRISIL Inclusix Index 2011 for financial inclusion, Gujarat was in the Below Average category in financial inclusiveness (with score between 25.0 and 40.0) on three parameters like- bank penetration, credit penetration and deposit penetration. Whereas overall India's Inclusix 2011 score was just at the entry level of above average category with a 40.1 score between 40.1 to 55.0 scores on a overall score of 100 . (CRISIL Inclusix 2013) India's overall progress in financial inclusion can be viewed from the fact that during 20092011 India's Inclusix score had improved from a low level of 35.4 in 2009 to 37.6 in 2020 and to 40.1 in 2011 and further to 42.8 in 2012. The improvement in India's overall Inclusix score in 2011 was largely driven by gains across all three dimension, particularly in deposit penetration (DP). (CRISIL Inclusix 2013)

However Gujarat has slipped its ranking from the $17^{\text {th }}$ position in 2009 to $18^{\text {th }}$ position in 2011 and further to $19^{\text {th }}$ position in 2012 in terms of Inclusix score. The state's Inclusix score in 2012 was 40.6 which are 2.2 points below the national average of 42.8 in 2012. So Gujarat entered into above average category in terms of financial inclusion (CRISIL Inclusix, 2014). Various studies have confirmed similar results across financial inclusion status in different states in India. By taking three parameters like Availability Index, Access Index and Usage Index when overall Financial Inclusion Index was constructed (on a scale of 0-1 on a methodology similar to UNDP's HDI construction) for 18 states of India, it was found that by Aug 2011, Gujarat was in the low financial inclusion category (with a score of 0.210 within 0 to 0.3 ) whereas states like Maharashtra, Tamil Nadu and Karnataka were in high financial inclusion category, with top 3 ranks respectively. Guajarat's rank was 11 out of 18 states (Meher, 2014). The present study envisages examining the level of financial inclusion in the informal sector of Gujarat by conducting primary survey in Gandhinagar district.

\section{Literature Review}

Various studies on unorganized and informal sectors in different parts of India and other studies have been conducted to study the level of financial inclusion at the bottom of the population pyramid. There is difference in level of Financial inclusion level in Urban and Rural areas, nationwide it is 36\%, while in rural areas it is 32\%, urban account for 45\% (RBI 2013, CRISIL 2013), thus a majority of urban area is also excluded and as urban population expands the priority to make financial inclusion accessible to all becomes important (ADB Institute, 2014). Encouraging different means to spread Financial Inclusion among daily wage workers of Tenali region, Andra Pradesh, India such as utilization of smart cards, engagement with Business correspondents, awareness drive by banks in private and public sector were noted (Divya, 2013). 
Importance of utilization of India post as means to cover financially excluded in the rural areas, use of business correspondents and business facilitators in the semi-urban areas, and agency banking micro finance institutions are essential part in financial expansion (Paramsivan and Ganeshkumar, 2013). Internal remittances the largest and the only source of income for the rural poor A large number of India's domestic migrants are excluded from the formal finance. "Migrants are often from low income groups and work on daily basis finding it difficult to send money back home due to lack of means, thus they depend on money lenders and correspondents which charge high interests" (Thorat, 2007).

In spread of Financial Inclusion by using mobile banking technology and other innovative means, still India is far from being adequate. Only $2.2 \%$ use mobile banking technology to number of mobile phone connections, this shows lack of awareness among people. It is alarming that only $6.9 \%$ of the Indian population uses cheques to make payments, while $2 \%$ of population uses electronic cards to make payments. Savings in financial institutions is around $11.6 \%$ in India as compared to $32 \%$ in China (Memdani \& Rajyalakshmi, 2013). Financial Inclusion through Micro finance has several advantages for rural development and inclusive growth of the poor (Sahoo and Behera, 2014). Developing technology that is user friendly, affordable and accessible to all is need of hour. For instance, banks could develop micro credit products for individuals (Mckinsey, 2010). The state of Gujarat has achieved considerable level of Financial Inclusion but it still scores low on financial Inclusion index. Banks have adopted BC models for delivery of financial services to uncovered villages, 614 out of total 622 are covered through BC Model. "SHG bank linkage programmer and government schemes have seen tremendous progress in financial inclusion of the state. Significant progress was made in the year 2011" (Raman, 2012). In another study of Gandhinagar district, it was observed that after declaration of "No-Frill Accounts" by RBI, in 70 per cent of the households had bank accounts remaining 12.7 per cent did not have means to any financial services. 87.3 per cent of individuals were covered under the financial inclusion drive by banks of which only 70 per cent could open bank account (so coverage only $70 \%$ ). Thus the report showed the reality differed from the predicted state of 100 per cent financial inclusion. Only 84.1 per cent respondents were acquainted with bank facilities, which was limited to only three major facilities namely loan facility (63.7\%), money transactions (40.6\%), and saving scheme (25.3\%). People from BPL and small land owners were not covered under Financial Inclusion and the spread of bank services is not even (MGLI, 2009).

The Present Study: The present study aims to study the state of Financial Inclusion in Gujarat, with special reference to Gandhinagar district. There remains research gap of studies of financial inclusion in unorganized and informal sector of Gujarat. To explore and explain low to moderate level of Financial Inclusion in Gujarat, that to examine the state of financial inclusion in informal sector where the reach of financial inclusion may be very low and may come at rather slow pace, a primary survey is conducted by taking a sample size of 100 individuals (natives of Gujarat) working in the unorganized sector in Gandhinagar district. In the study both male and female workers from both rural areas (4 villages-i.e. Raysan, Koba, Valat, Bhaatgam) and urban and semi-urban areas (Gandhinagar city and Chandkheda) were included. Convenient sampling method with structured questionnaire was used and data was collected during Mar-April 2015. Further to examine the possible causes of ownership of deposit accounts, binary logistic regression model is estimated, which may guide us in identifying the major important variables. On the basis of above findings possible solutions may be identified in order to improve the state of Financial Inclusion in Gujarat.

\section{Analysis of Primary Survey and Data Interpretation}

The findings are interpreted as follows:

Gender, Age and Family-size Classification: Out of 100 respondents, 31 were Females and 69 were Males. Respondents were from 3 age groups: youth (18-25 years), middle age (26-46years) and upper age (47-55 years). Age distribution shows highest number of people were in 26-46 age group (68\%) belonging to Middle age; whereas youth were of $17 \%$ and upper aged people were of $15 \%$. Family- size break-up of the respondents reveals that maximum percentage of males (47\%) and females $(22 \%)$ belonged to the family size 4 to 6 , which combined form $69 \%$ of the respondents. Only $16 \%$ respondents had smallest family size of 3 or less, which included 10\% males and 6\% females.15\% respondents had bigger families ranging between 7 to15. 
Occupation and Income Classification: Respondents were engaged in various occupations like, institutional services (19\%) like housekeeping, security guards, gardener, deliveryman etc; household services (17\%) like domestic helpers, sweepers, laundrymen, cook; small shop ownership \& menial services (11\%) like shopkeepers, tailor, barber, cobbler etc; transport service providers (11\%) auto-rickshaw driver, conductor, cab driver etc; street vending (10\%) fast food vendors, vegetable vendors, fruit sellers, newspaper vendor etc; daily wage labor (10\%) like shop assistants, restaurant assistant, construction site workers etc; agricultural and allied activities (7\%) like farmers, shepherds etc; industrial services (6\%) like plumber, electrician, welder, mechanic, machine operator etc; and others. Respondents' revealed monthly income ranged from Rs.2000 to 22,000. Respondents were divided in 5 income groups based on their revealed monthly incomes viz. (i) Rs. 5000 \& below, (ii) Rs. 5000-10000, (iii) Rs. 10000-15000, (iv) Rs. 15000-20000, (v) Rs. 20000-25000. Income distribution of the respondents reveals that maximum percentage of people were from income category of Rs. 5000-10,000 (40\%) and closely followed by income category of Rs. 5000 \& below (38\%) (Figure 1). 16\% respondents were from income category of Rs. 10000-15000, whereas minimum 3\% each of respondents were from Rs. 15000-20000 and Rs. 20000-25000 categories. Gender break up in income revealed that maximum percentage of males were having lowest income of Rs. 5000 \& below (27\%); and minimum in 15000-20000 and 20000 to 25000 income category. Likewise, maximum percentage of females had monthly income of Rs. 5000 to 10000; and minimum in category Rs.15000 to 20000 and Rs. 20000 to 25000 category (Figure 1).

Figure 1: Gender-wise Income Distribution (\%)

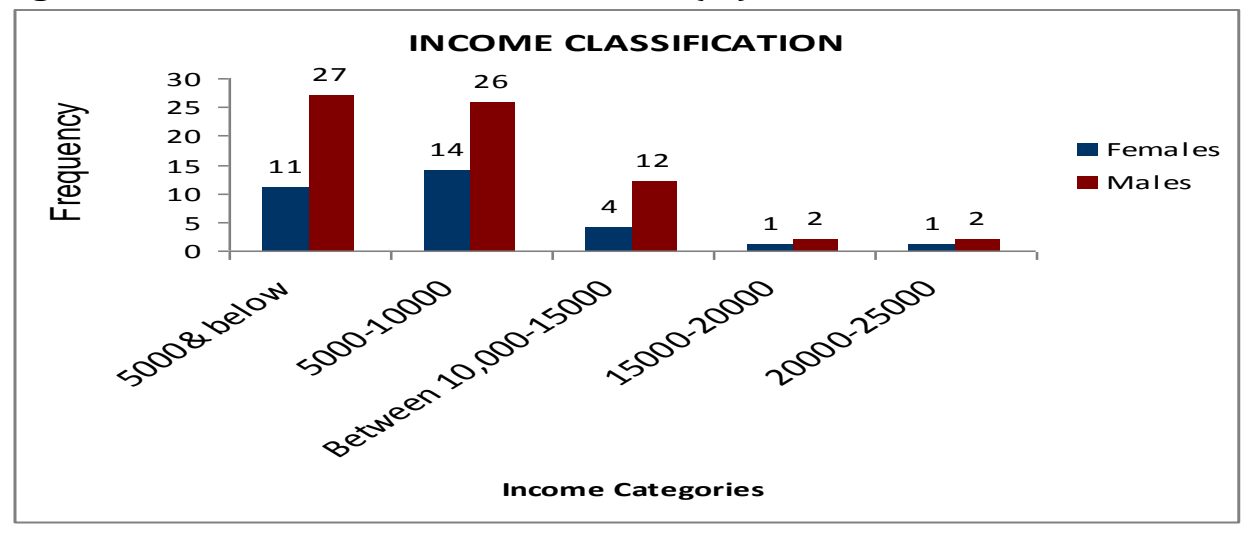

Access to Financial Services: Ownership of bank or postal deposit account (savings or current) is the first indicator of financial inclusiveness. It was revealed that $76 \%$ of respondents were having at least a deposit account whether in a bank or a post office and $24 \%$ didn't possess a deposit account (Figure 2). That means a significant proportion of respondents were out of the coverage of financial services. This revelation becomes further important as the current study was conducted after the implementation of Pradhan Mantri Jan Dhan Yojana (PMJDY) on August 28, 2014 by the government of India, which aims to provide maximum coverage to the excluded people in terms of zero balance no-frills bank accounts. Moreover, $15 \%$ respondents owned both a bank account and postal account. That means Indian postal system had contributed only $15 \%$ deposit account ownership in the sample, which is comparative very low, despite India having a very vast network of post offices, with over 1, 55,000 branches which is twice as large as the outreach of all commercial banks in India put together (Report of Expert Committee on Harnessing the India Post Network for Financial Inclusion, 2010). Gender-wise access to financial services reveals that out of total account holders about $67 \%$ were males (i.e.51\% of total sample) and $33 \%$ were females (i.e. $25 \%$ of total sample), who had a bank or postal deposit account. That further shows gender biasness against the females in terms of access to financial services despite numerous efforts by Government of India and RBI. Likewise, among the non-holders of accounts $25 \%$ were females (i.e. $6 \%$ of total) and $75 \%$ (i.e. $18 \%$ of total) were males. The study also revealed that the most common reason for not having formal bank account was lack of enough income and savings. A larger gap between males and females on ownership of formal bank account can be due to lack of women empowerment and employment opportunities as the sample respondents belong to the informal sector. 
Figure 2: Individual Deposit Account Ownership (\%) in Banks/Post Offices

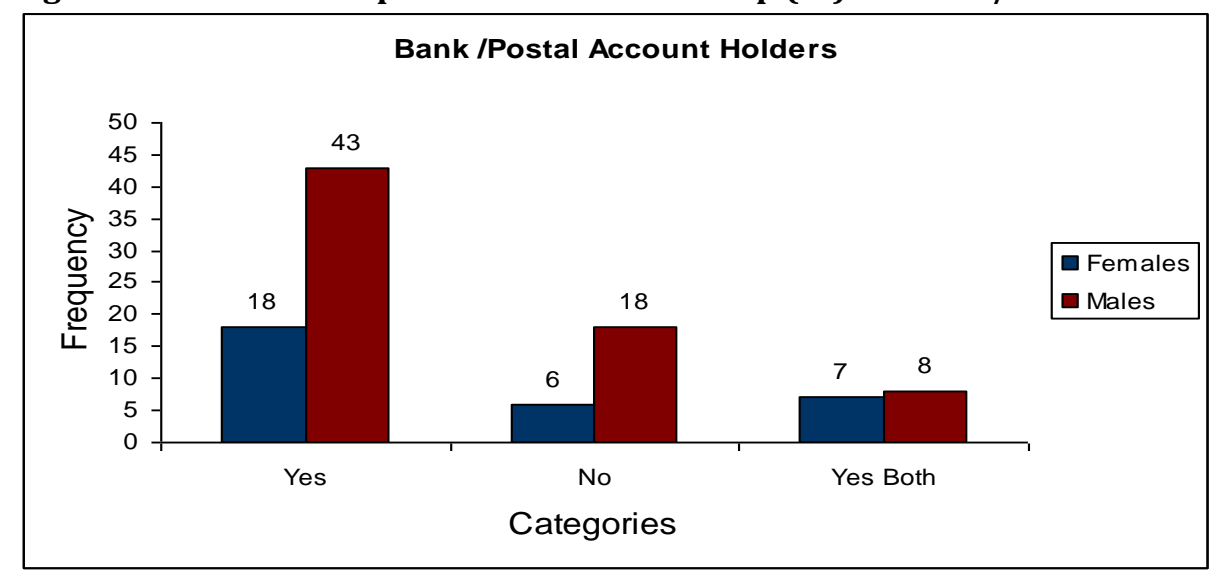

Apart from individual ownership of deposit account, household ownership i.e. ownership of deposit account by any of the respondents' family members may also reflect accessibility of financial services at the household level. As expected, an increasingly higher proportion of females reported about any of their family members having a deposit account. 26 out of 31 females (i.e. 83.87\%), revealed members of their family having bank accounts, while in case of males only $57.97 \%$ had their family members with bank accounts.

Figure 3: Deposit Account Ownership by Any Family Member

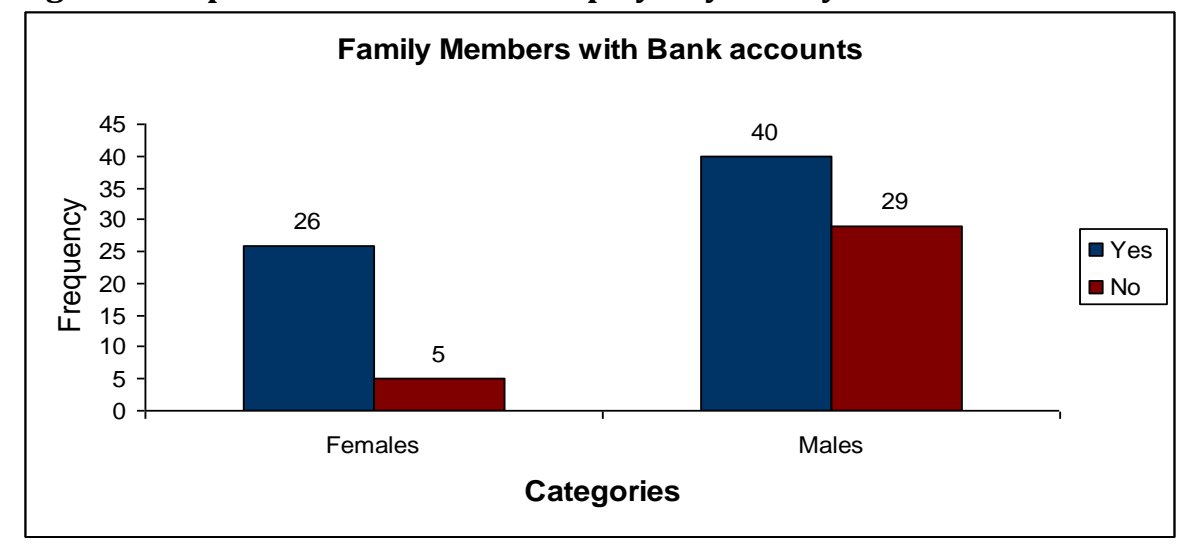

Credit plays a major role in providing crucial financial services to people. That's why owning a bank/postal account is not a sufficient criterion of financial inclusiveness, though it is a necessary condition. So far as credit accounts are concerned, study reveals that $60 \%$ respondents had taken credit from formal sources of finance that is they had credit accounts either with banks, micro-finance institutions or co-operative societies. A significant proportion i.e. 25\% respondents had taken credit from informal sources like local money lenders, relatives, family friends etc. (Figure 4) 15\% reported not having taken any loan from any sources. Banks were the highest providers of credit (39\% of total respondents), followed by local money lenders $(19 \%)$ and Cooperative Societies (18\%). A significantly small dependence was on the MFIs i.e. only 3\%. This shows a significant high proportion of respondents are still dependent on local money lenders. This may be due to the fact that there is insufficient penetration of banks' and MFIs credit services to the sampled people. Out of those who had taken credit from formal sources one-third i.e. $33.3 \%$ were females and $66.7 \%$ were males, which again suggests less access of credit for the women. Likewise, out of those who had taken credit from informal sources, $28 \%$ were females and $72 \%$ were males, which shows access to credit for women in the informal sources is also low. Here MFIs and co-operative societies can play major role. In case of Cooperative societies female respondents depend on small cooperative groups as means to get credit, which comes to $32.25 \%$ of total females, that is $55.5 \%$ of total number of credits from co-operatives. Likewise male respondents' dependence amounts to $11.59 \%$ of total males. Out of total number of bank credit holders, 
$23.1 \%$ were females and $76.9 \%$ were males, that itself shows banks have failed to provide enough credit facilities to the women.

Figure 4: Sources of Credit taken by the Respondents

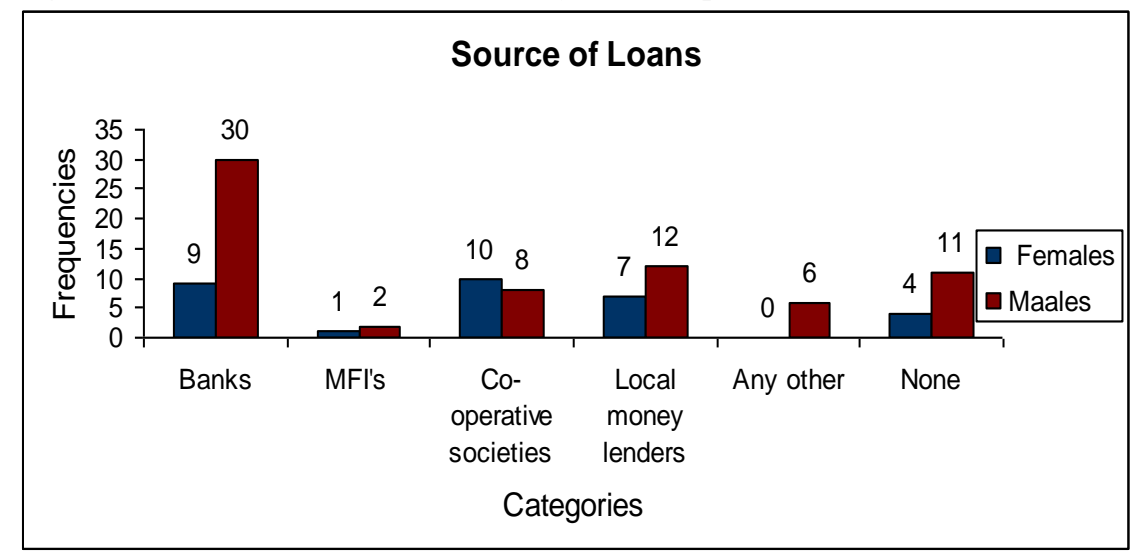

Availability of Financial Services: For mapping the availability of financial services availability of banking services is taken as indicator. Availability of Banks refers to banks penetration in particular area. If banks are available it would make it easier for individuals to access bank services. A significantly high proportion i.e. $87 \%$ of respondents revealed that banking service was easily available in their area of residence. Both Males and Females have significantly better results in segment of availability $(85.5 \%$ of males and $90.3 \%$ of females). Proximity of banks is another dimension of availability of financial services, which shows how close or far are banks located from individuals' residence. The study revealed that banks were located in the nearby proximity for most respondents ( $75 \%$ of total) and for both males and females within 2 to 5 kilometers distance. For a low percentage (11\%) of people bank availability was at more than $10 \mathrm{~km}$ distance.

\section{Figure 5: Frequency of Visits by the Business Correspondents from Banks}

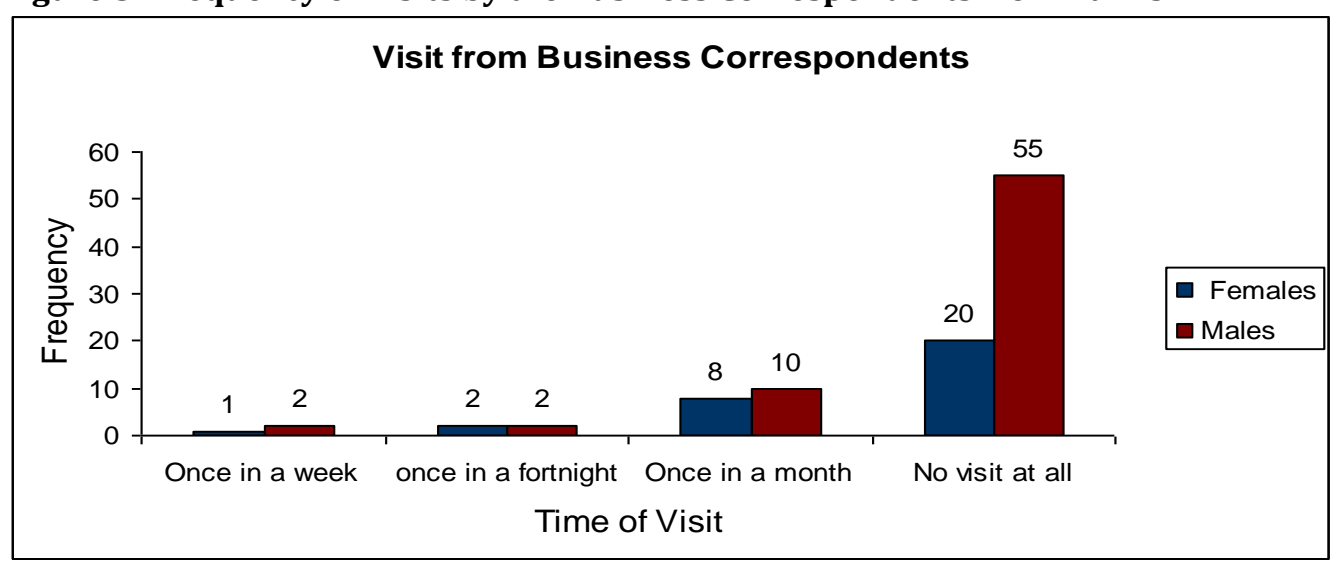

As discussed above, in places where there is no bank branches, visits by Business Correspondents (BC's) are provided by banks, which is an important component of financial inclusiveness. As the state of Gujarat depends on $\mathrm{BC}$ model for expansion of financial inclusion it becomes crucial to examine whether group of individuals have come across BC's. The study reveals that a whopping $75 \%$ respondents reported of no visit by the BCs. Only $25 \%$ respondents had come across BCs' visiting their areas once in a week to once in a month frequency (Figure 5). So this suggests that for further expansion of banking services to the excluded segments frequency of BCs' visit should be increased by the banks.

Usage of Financial Services: From the study it was observed that $45 \%$ of the total respondents deposit money on regular basis in the banks. Out of total regular depositors, females account for $37.77 \%$ while males 
were about $62.22 \%$. While non-regular depositors account to $49 \%$. Out of non-regular depositors, females account for $26.53 \%$ while males were of $73.46 \%$. This shows the proportion regular users of bank account were lower than the non-regular ones, but more proportion of females deposited regularly than the nonregular females. This reveals females may be more willing to use financial services if given opportunity and included financially. The study further revealed that respondents were mostly dependent on public sector banks (97\%) such as SBI, Dena Bank, Bank of Baroda, Oriental Bank of Commerce. After PM's Jan Dhan Yojana these banks have aggressively covered large number of customers. Share of private sector banks among the respondents was low, only 3\%. Further study shows usage of bank services apart from depositing or borrowing money has not broaden to great extent. Here performance of both males and females is poor in using services such as transfer payments, insurances, tax payment and like-wise which are provided by banks are not availed (Figure 6).

\section{Figure 6: Usage of Bank Services Apart From Depositing}

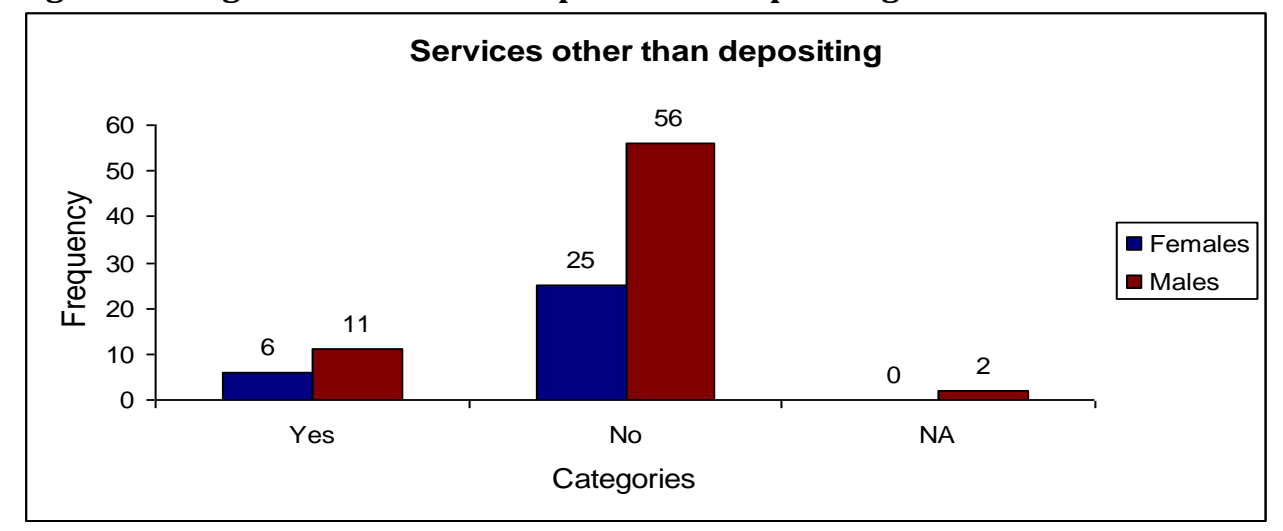

Figure 7: Number of Years of using Bank Accounts

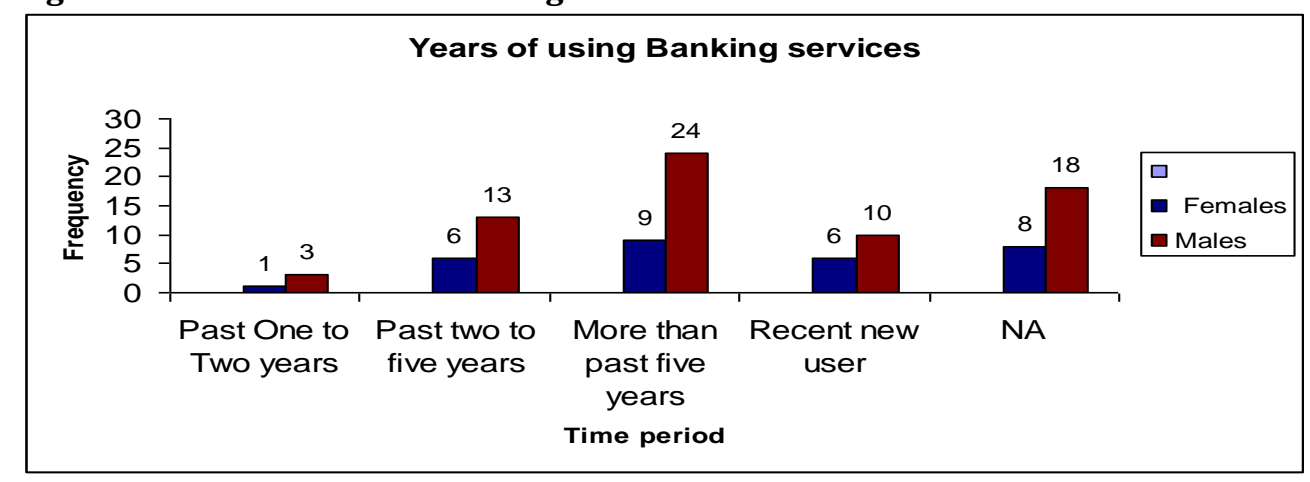

Figure 8: Operation Bank Accounts

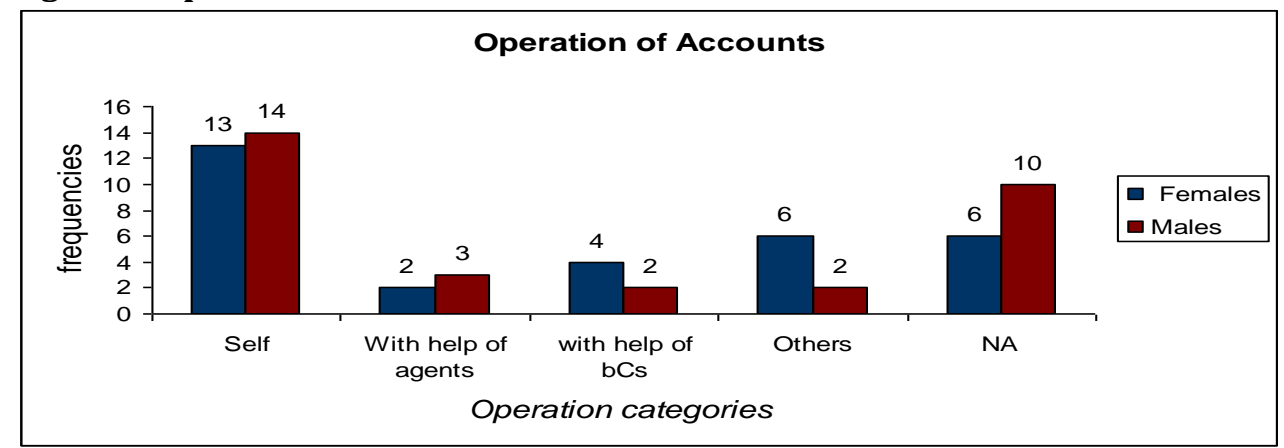


Above chart shows the number of years since when individuals have been using Bank accounts. As observed Males have outperformed Females in this particular segment of usage. (Figure 7) Given to the Male dominance in the Indian society this can be the possible reason. In understanding processes of banking processes, females lag behind in terms of comprehension as compared to males; hence there is a need to impart basic knowledge in terms of understanding bank processes in general. Figure 8 shows Operation of Bank Accounts showing larger number of individuals prefers operating bank accounts on their own. Individuals do rely on BC's and agents. In case of awareness of various financial services provided by India Post, it was very low in both Males (12\%) and Female (6\%). Unawareness of financial services by India Post amounts to about $82 \%$ of total respondents. Online facilities, use of Information, Communication and technology can help expand financial inclusion. Still a majority of individuals do not avail online Banking facilities i.e. only $15 \%$ respondents in the study were using online banking facilities.

\section{Figure 9: Usage of Various Smart Cards}

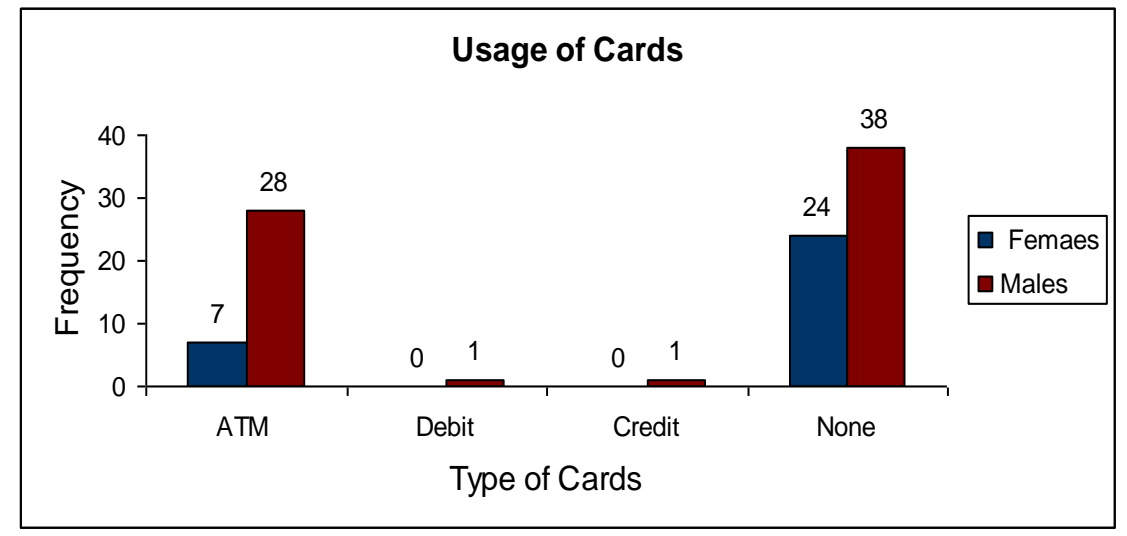

To promote financial inclusion use of smart cards such as ATM's, Debit, Credit cards becomes important. After Jan Dhan Yojana the number of ATM card users, have risen though rise is not significant in terms of usage and holding. $62 \%$ respondents didn't have any smart card. Further Individuals revealed that they had ATM cards but do not know how to operate. (Figure 9)

Figure 10: Awareness of Various Financial Inclusion Programs

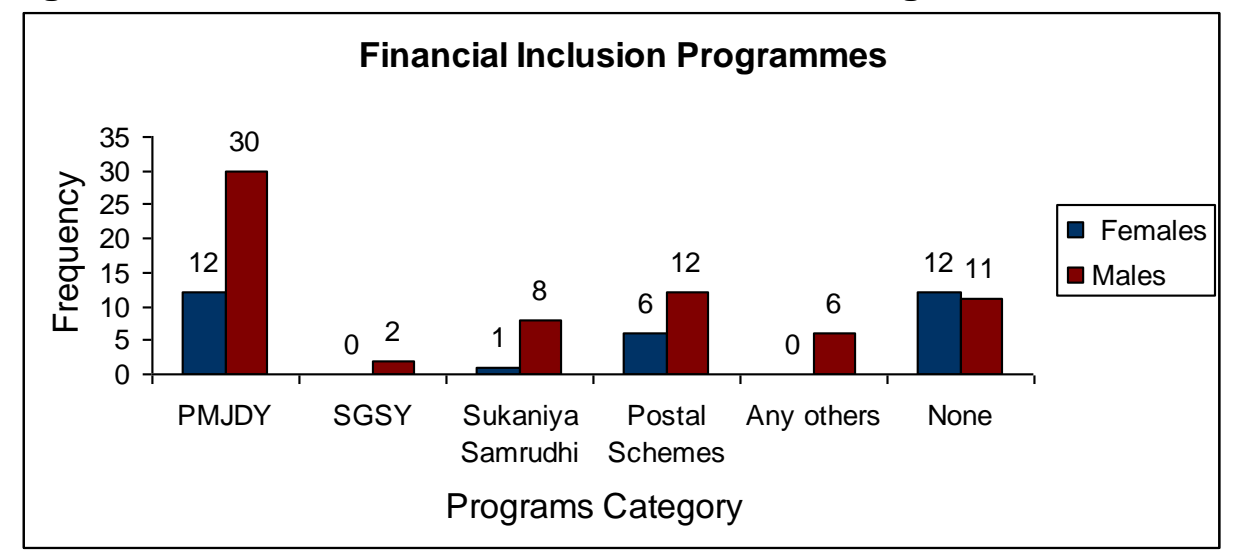

Since 2000's several programs to expand financial inclusion in India have been established but the response to the program is not adequate, hence in 2005 and 2008 and again in 2014 several reforms and new programs have been launched. Prime Minister's Jan Dhan Yojana launched in August 2014 is the fasted growing government scheme in the world. As per study observation, the awareness for PMJDY is highest among the males followed by postal schemes. Also among Females the awareness for PMJDY is the highest. There are cases wherein individuals are unaware of the Financial Inclusion programs. Hence, awareness towards such financial programs must be advanced (Figure 10) 
Regression Model: Second part of the analysis deals with explaining the deposit account ownership among the respondents. For this regression analysis has been conducted and binary logistic or logit model has been estimated for the study.

A logistic function is defined as,

$L_{i}=P(y=1 \mid x)=\log \left[P_{i} /\left(1-P_{i}\right)\right]=\beta_{0}+\beta 1 X 1+\beta 2 X 2+\beta 3 X 3+\beta 4 X 4+\varepsilon$

Where, $\mathrm{P}_{\mathrm{i}} /\left(1-\mathrm{P}_{\mathrm{i}}\right)=$ odds ratio of probability of success to probability of failure, where,

$\mathrm{P}_{\mathrm{i}}=$ probability of success or probability of presence of a trait and,

$1-\mathrm{P}_{\mathrm{i}}=$ probability of failure or probability of absence of trait

In fact, in logit model, the odds ratio $[\mathrm{Pi} /(1-\mathrm{Pi})]=\exp (\beta 0+\beta 1 \mathrm{X} 1+\beta 2 \mathrm{X} 2+\beta 3 \mathrm{X} 3+\beta 4 \mathrm{X} 4+\varepsilon)$ i.e. it is an exponential function of the $X$ variables), which then leads to linearization by taking logarithm of odds ratio i.e.

$\log \left[P_{i} /\left(1-P_{i}\right)\right]=\beta_{0}+\beta 1 X 1+\beta 2 X 2+\beta 3 X 3+\beta 4 X 4+\varepsilon$

Above function is known as logit or logistic function which is estimated in cases where the dependent variable is binary having to possibilities of occurrence. That means, $P(y=1 \mid x)$ denotes probability that $y$ takes value 1 (success) and hence 0 otherwise (failure).

Thus, following logit model is estimated and binary logistic regression is run:

$P($ Bankacc $=1 \mid x)=\log \left[P_{i} /\left(1-P_{i}\right)\right]=\beta_{0}+\beta 1$ Income $+\beta 2$ Education $+\beta 3$ Female $+\beta 4$ Bankavail $+\varepsilon$

Where, $\mathrm{y}$ is a binary variable i.e.

$\mathrm{y}=$ Bankacc $=1$ if a person has a bank/postal account;

$=0$ otherwise

$\mathrm{X} 1=$ Income i.e. monthly income of the individual

$\mathrm{X} 2=$ Education i.e. number of years of schooling of the individual

$\mathrm{X} 3=$ Female (dummy) $=1$ if the person is female or 0 otherwise

$\mathrm{X} 4=$ Bankavail (dummy) $=1$ if bank / postal service is available near to the residence, or 0 otherwise

\section{Regression Output}

\section{Classification Table ${ }^{a, b}$} Observed

\section{Predicted}

Do You have Bank account or postalPercentage
account or account in both ? Correct

Do You have Bank account orNo

Step 0 postal account or account in No Yes Overall Percentage

$\begin{array}{lll}0 & 25 & .0\end{array}$

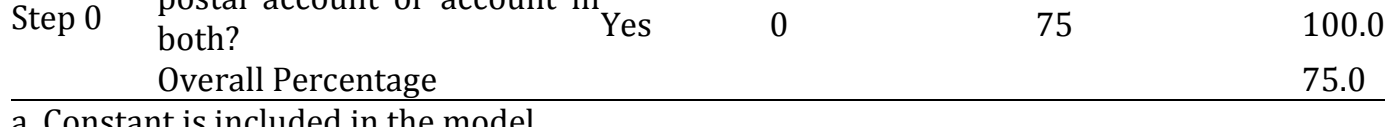
a. Constant is included in the model.
b. The cut value is .500

\section{Model Summary}

\begin{tabular}{lcccc}
\hline Step & $\mathbf{- 2 ~ L o g ~ l i k e l i h o o d ~ C o x ~ \& ~}$ & $\begin{array}{c}\text { Snell } \\
\text { Square }\end{array}$ & $\begin{array}{c}\text { RNagelkerke } \\
\text { Square }\end{array}$ & $\mathbf{R}$ \\
\hline 1 & $105.027^{a}$ & .072 & .106 \\
\hline
\end{tabular}

a. Estimation terminated at iteration number 5 because parameter estimates changed by less than .001 . 
Variables in the Equation

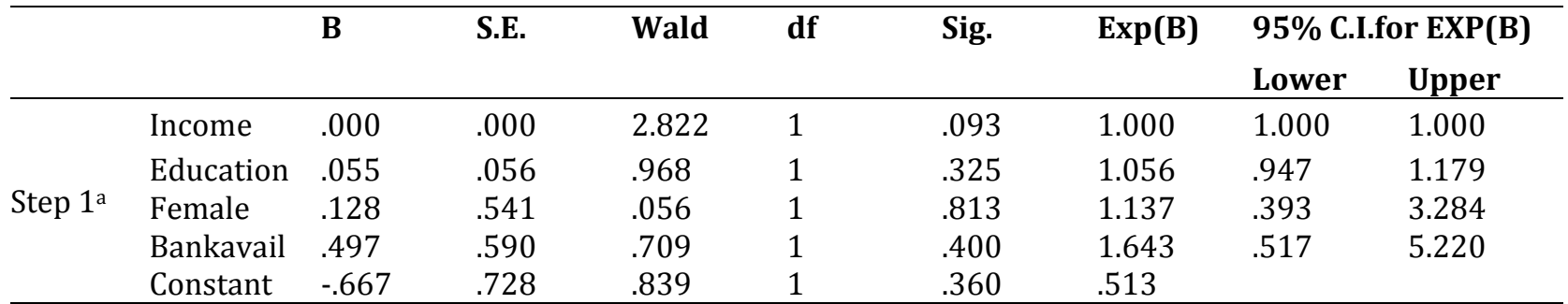

a. Variable(s) entered on step 1: Income, Education, Female, Bankavail.

Interpretation of Regression Analysis: Out of the four variables, only Income explains the probability of having a bank account, which has positive relationship with the dependent variable as expected, which is also significant at within $10 \%$ significance level. That is when monthly income of individuals increases by one Rupee the chances of owning a bank account also increase by about one time as shown by exp (B) values. Level of education and bank/postal availability in the nearby areas though show positive relationship with the odds of owning a bank account, but they are not significant even at 10 per cent level, though they show increase in the odds of bank account ownership by more than one times when schooling increases by one year and if a bank/post office is present in nearby area. Being female also does not explain a significant relationship with owning a bank account. So, what important implication one derive is that participation in income generating activity is what has significantly related with ownership of a bank account, rather than level of education or availability of banking services in nearby areas. A possible reason for this may be that the formal education is not sufficient for financial literacy, and hence even if a bank is available in nearby area due to lack of awareness about usage of financial products and processes, it may not lead to effective conversion into ownership of bank account.

\section{Conclusion}

The study revealed that in Gandhinagar district, majority, but not all, of respondents were having at least a deposit account whether in a bank or a post office and $24 \%$ didn't possess a deposit account. That means a significant proportion of respondents were out of the coverage of financial services. Indian postal system had contributed only $15 \%$ deposit account ownership in the sample, which is comparative very low, despite India having a very vast network of post offices. Gender-wise access to financial services reveals that out of total account holders about $67 \%$ were males (i.e.51\% of total sample) and $33 \%$ were females (i.e. $25 \%$ of total sample), who had a bank or postal deposit account. That further shows gender biasness against the females in terms of access to financial services despite numerous efforts by Government of India and RBI. Likewise, among the non-holders of accounts $25 \%$ were females (i.e. $6 \%$ of total) and $75 \%$ (i.e.18\% of total) were males. The study also revealed that the most common reason for not having formal bank account was lack of enough income and savings. A larger gap between males and females on ownership of formal bank account can be due to lack of women empowerment and employment opportunities as the sample respondents belong to the informal sector.

Further study reveals that $60 \%$ respondents had taken credit from formal sources of finance. A significant proportion i.e. 25\% respondents had taken credit from informal sources like local money lenders, relatives, family friends etc. $15 \%$ reported not having taken any loan from any sources. Banks were the highest providers of credit (39\% of total respondents), followed by local money lenders (19\%) and Cooperative Societies (18\%). A significantly small dependence was on the MFIs i.e. only 3\%, so the role of MFIs is still left to be filled up. The study revealed that a whopping 75\% respondents reported of no visit by the BCs. Only $25 \%$ respondents had come across BCs' visiting their areas once in a week to once in a month frequency. So scope for BCs visit still remains to be increased for financial expansion. The proportion of regular users of bank account was lower than the non-regular ones, but more proportion of females deposited regularly than the non-regular females. This reveals females may be more willing to use financial services if given opportunity and included financially. Lastly, income generating activity is what has significantly related with ownership of a bank account, rather than level of education or availability of banking services in nearby 
areas. A possible reason for this may be that the formal education is not sufficient for financial literacy, and hence even if a bank is available in nearby area due to lack of awareness about usage of financial products and processes, it may not lead to effective conversion into ownership of bank account. So beyond penetration of banks, government has to put serious thought on increasing financial literacy and awareness about using banking services and easiness of understanding of banking processes.

\section{References}

CRISIL Inclusix. (2013). An Index to Measure India's Progress on Financial Inclusion, CRISIL, June.

Divya, K. H. (2013). A Study On Impact of Financial Inclusion With Reference To Daily Wage Earners. Journal of Business Management \& Social Sciences, 2(6).

Financial Access Survey. (2010). World Bank, Washington D.C.

Meher, S. (2014). Financial Inclusion in India: An Inter-State Analysis, in Mishra, P. et al ed. Financial Inclusion, Inclusive Growth and The Poor, 2014, New Century Publication, New Delhi.

Memdani, L. \& Rajyalakshmi, K. (2013). Financial Inclusion In India. International Journal of Applied Research and Studies, 2(8).

MGLI. (2009). Evaluation of 100 per cent Financial Inclusion in Gandhinagar District of Gujarat, Mahatma Gandhi Labor Institute, Ahmadabad.

Paramsivan, C. \& Ganeshkumar, V. (2013). An Overview of Financial inclusion in India. International Journal of Management and Development Studies, 3(1).

Mckinsey. (2010). Global report on Financial Inclusion

Raman, A. (2012). Financial inclusion and Growth of Indian Banking System. International Journal of Business and Management, 1(3).

Ray, D. \& Rout, H. (2014). Financial Inclusion Models in India', in Mishra, P. et al ed. Financial Inclusion, Inclusive Growth and The Poor, 2014, New Century Publication, New Delhi.

Report of The Expert Committee on Harnessing The India Post Network for Financial Inclusion. (2010). Department of Post, Ministry of It and Communication, GoI, New Delhi, June.

Report of The Committee on Financial Inclusion. (2008). RBI, at www. rbi.org.in

Sahoo, P. \& Behera, A. (2014). Financial Inclusion Through Microfinance, in Mishra, P. et al ed. Financial Inclusion, Inclusive Growth and The Poor, 2014, New Century Publication, New Delhi.

Shamaka, R. \& Gakhar, S. (2015). Advancing Financial inclusion Beyond the Jan Dhan Yojana', Brookings India Impact Series, Development and Governance January, Brookings Institution India Centre, New Delhi.

Thorat, U. (2007). Deputy governor's speech, RBI, at www. rbi.org.in

United Nations. (2006). Building Inclusive Financial Sectors for Development, United Nations, New York 